\title{
Pengaruh Kerja "Melunyah" terhadap Kondisi Fisiologis pada Kerbau Rawa di Kabupaten Bengkulu Selatan, Bengkulu
}

\author{
The effects of "Melunyah" on physiological parameters of swamp buffalo in Bengkulu Selatan \\ District, Bengkulu Province. \\ Dwatmadji dan Ipantri
}

Jurusan Peternakan Fakultas Pertanian Universitas Bengkulu

Jalan Raya Kandang Limun Bengkulu Telp. (0736) 21170 Pst 134.

\begin{abstract}
The aim of this research was to evaluate the physiological changes on swamp buffalo used for draft animal power of preparing rice field under traditional system called "Melunyah" in Bengkulu Selatan District, Bengkulu Province. Twelve buffaloes used was 3-8 years old having Body Condition Score (BCS) of 7-8 and liveweight of $175-225 \mathrm{~kg}$. Physiological parameters measured were rectal temperature, respiration, and pulse rate in which they were measured during pre-work (Pre-Kerja), during working (Saat-Kerja), dan soon as working terminated (Post-Kerja). Research data was tabulated and analyzed for means difference using SPSS software version 11. The present research showed that all physiological parameters measured during Saat-Kerja and PostKerja were higher than that of the Pre-Kerja. Mean physiological increment due to Melunyah work were $1.05^{\circ} \mathrm{C}$ (rectal temperature), $60.25 \mathrm{x} /$ minute (respiration) dan $47.4 \mathrm{x} /$ minute (pulse rate). Physiological changes due to Melunyah can be categorized as light work and was not detrimental to the buffalo performances.
\end{abstract}

Key words: draft animal power, buffalo, physiology

\begin{abstract}
ABSTRAK
Penelitian ini untuk mengevaluasi perubahan fisiologis ternak kerbau yang digunakan sebagai ternak pengolah lahan rawa yang akan ditanami padi lokal, yang dikenal sebagai sistem "melunyah". Penelitian dilakukan di kecamatan Manna, Kabupaten Bengkulu Selatan, Propinsi Bengkulu. Jumlah keseluruhan kerbau yang digunakan dalam penelitian ini adalah 12 ekor, yang telah dewasa tubuh, dan berumur rata-rata 3-8 tahun dengan kondisi Body Condition Score (BCS) 7-8, dan berat badan antara 175-225 kg. Parameter fisiologis yang diukur adalah temperatur rektal, respirasi, denyut nadi yang diukur pada pada periode yang berbeda, yaitu pada saat kerbau sebelum "melunyah" (Pre-Kerja), saat kerbau "melunyah" (Saat-Kerja), dan setelah kerbau selesai "melunyah" (Post-Kerja). Hasil penelitian ditabulasikan dan rata-rata nilai fisiologis diuji dengan DMRT untuk mengetahui perbedaan antar mean. Untuk analisis statistik digunakan software SPSS version 11. Hasil penelitian menunjukkan1 bahwa semua parameter fisiologis yang diukur pada Saat-Kerja dan Post-Kerja secara nyata $(\mathrm{P}<0,05)$ lebih tinggi dibanding pengukuran pada Pre-Kerja. Rata-rata kenaikan parameter fisiologis saat ternak kerja dibanding sebelum ternak kerja adalah $1,0^{\circ} \mathrm{C}$ (temperatur rektal), 60,25 x/menit (respirasi) dan 47,4 $\mathrm{x} / \mathrm{menit}$ (denyut nadi). Sedangkan perubahan fisiologis yang terjadi akibat "melunyah" termasuk dalam kategori kerja ringan, yang tidak berbahaya bagi ternak kerbau.
\end{abstract}

Kata kunci: ternak kerja, kerbau, fisiologi

\section{PENDAHULUAN}

Ternak kerja bagi petani dan pembuat kebijakan di berbagai bagian dunia sebagai teknologi yang tepat guna (appropriate), terjangkau secara ekonomi (affordable) dan berkelanjutan (sustainable) yang hanya butuh input eksternal minimum (Starkey, 1995). Ternak kerja juga dapat memberikan tenaga untuk memproduksi pangan dan untuk transportasi bagi petani dengan skala usaha kecil dengan sumber daya ekonomi yang lemah (Kotsokoane, 1998). Sampai saat ini, ketergantungan petani terhadap kebutuhan ternak kerja masih sangat relevan (Ramaswamy, 1985), apalagi terhadap kebutuhan 
khas lokal yang mempunyai karakteristik lahan yang tidak memungkinkan adanya intervensi traktor pengolah lahan (Pearson and Dijkman, 1994)

Para petani di Bengkulu Selatan banyak yang secara tradisionil menggunakan kerbau untuk mengolah lahan rawa dangkal yang akan ditanami padi, yang dikenal dengan "melunyah". "Melunyah" dilakukan dengan menggembalakan beberapa kerbau secara berpasangan (3-9 ekor) dan berjalan-jalan secara berkeliling disepanjang lahan yang diolah. Dengan cara ini maka tanaman liar yang sebelumnya tumbuh dilahan rawa-rawa akan terinjak-injak oleh kerbau masuk kedalam dasar rawa, dan sekaligus lahan dapat siap ditanami dengan padi rawa.

Penelitian ini dilakukan untuk mengevaluasi penggunaan ternak kerbau untuk "melunyah" dan mengevaluasi perubahan fisiologisnya. Perubahan fisiologis yang terlalu tinggi akan dapat membahayakan performans produksi dan reproduksi ternak kerbau.

\section{MATERI METODE}

Sebanyak 12 ekor Kerbau dewasa (umur 3-8 tahun) digunakan dalam penelitian ini dengan BCS (body condition score) sekitar 7-8 (range 1-9). Pemilihan ternak dilakukan terutama dengan mempertimbangkan berat badan (175-225 kg) dan kondisi BCS yang diusahakan seseragam mungkin. Penelitian dilakukan selama 2 bulan dan berlokasi di kecamatan Manna, Kabupaten Bengkulu Selatan, Propinsi Bengkulu.

Beberapa alat yang dipakai adalah alat ukur (tali meteran), stopwatch, thermometer rektal, lux meter, dan thermometer basah dan kering untuk mengukur kelembaban udara.

Semua kerbau yang digunakan untuk melunyah diukur kondisi fisiologis (temperatur rektal, respirasi, dan denyut nadi), dibagi kedalam periode kerja yaitu Pre-Kerja (pengukuran yang dilakukan pada saat ternak dalam kondisi istirahat dan sebelum bekerja), Saat-Kerja (pengukuran yang dilakukan pada saat ternak sedang bekerja "melunyah"), dan Post-Kerja (pengukuran yang dilakukan segera setelah ternak selesai melakukan kerja "melunyah"). Pengukuran fisiologis pada PreKerja dan Post-Kerja dilakukan sebanyak 3 kali dengan interval waktu masing-masing 5 menit dan 10 menit, sedangkan Saat-Kerja dilakukan setiap 30 menit.

\section{HASIL DAN PEMBAHASAN.}

\section{Kemampuan Kerja}

Hasil kemampuan kerja ternak kerbau yang digunakan untuk melunyah dapat dilihat pada Tabel 1.

Tabel 1. Rata-rata persen distribusi waktu kerja dan lama kerja "melunyah".

\begin{tabular}{lccc}
\hline \multirow{2}{*}{ Waktu Kerja } & \% Kerja Berdasarkan Waktu & \multicolumn{2}{c}{ Lama "melunyah" (\%) } \\
\cline { 3 - 4 } Pagi $(04.00-06.00)$ & 30,3 & $1-2$ jam & $2-3$ jam \\
Sore $(16.00-18.00)$ & 44,2 & 78,9 & 21,1 \\
Malam $(20.00-22.00)$ & 25,5 & 62,5 & 37,5 \\
\hline
\end{tabular}

Tabel 1 menunjukkan bahwa persentase penggunaan kerbau untuk "melunyah" tertinggi adalah pada sore hari $(44,2 \%)$, diikuti waktu kerja pagi dan malam hari. Walau waktu kerja dipilih secara turun temurun, nampaknya pemilik kerbau yang digunakan untuk melunyah tanpa disadari sudah memperhatikan aspek panas matahari yang dapat mempengaruhi kinerja kerbau yang digunakan untuk kerja. Panas matahari yang terik, terutama pada siang hari, dapat mempercepat respon fisiologis ternak kerbau mengingat kerbau adalah ternak yang kurang tahan terhadap temperatur lingkungan yang tinggi dibanding sapi. 
Secara rata-rata, lama "melunyah" mayoritas adalah 1-2 jam (62,5-78,9\%) dan terutama dilakukan pada pagi hari $(78,9 \%)$. Dengan demikian dapat diduga bahwa kerja "melunyah" tidak berat bagi ternak kerbau, mengingat ternak kerja dapat bekerja sampai dengan 4 Jam/hari selama 3 minggu berturutturut (Gemeda et al., 1995).

\section{Fisologis Ternak}

Pengaruh kerja terhadap kenaikan temperatur tubuh yang diukur pada temperatur rektal, respirasi, dan denyut nadi dapat dilihat pada Tabel 2.

Tabel 2. Nilai rata-rata temperatur rektal, respirasi, dan denyut nadi pada ternak kerbau yang digunakan untuk "melunyah" dan diukur pada Pre-Kerja, Saat-Kerja, dan Post-Kerja.

\begin{tabular}{lcccccc}
\hline \multirow{2}{*}{ Periode Kerja } & \multicolumn{2}{c}{ Temperatur Rektal $\left({ }^{\circ} \mathrm{C}\right)$} & \multicolumn{2}{c}{ Respirasi $(x /$ menit) } & \multicolumn{2}{c}{ Denyut Nadi (x/menit) } \\
\cline { 2 - 7 } & Pagi & Sore & Pagi & Sore & Pagi & Sore \\
\hline Pre-Kerja & $36,7^{\mathrm{a}}$ & $38,1^{\mathrm{a}}$ & $23,7^{\mathrm{a}}$ & $22,9^{\mathrm{a}}$ & $60,5^{\mathrm{a}}$ & $64,2^{\mathrm{a}}$ \\
Saat-Kerja & $37,7^{\mathrm{b}}$ & $38,4^{\mathrm{b}}$ & $77,8^{\mathrm{b}}$ & $83,4^{\mathrm{b}}$ & $110,0^{\mathrm{b}}$ & $109,3^{\mathrm{b}}$ \\
Post-Kerja & $37,3^{\mathrm{b}}$ & $39,0^{\mathrm{b}}$ & $75,9^{\mathrm{b}}$ & $84,9^{\mathrm{b}}$ & $107,4^{\mathrm{b}}$ & $110,5^{\mathrm{b}}$ \\
\hline
\end{tabular}

Superskrip dengan huruf yang berbeda yang berbeda pada kolom yang sama menunjukkan perbedaan yang nyata $(\mathrm{P}<0,05)$

Secara keseluruhan terlihat bahwa seluruh kerbau yang digunakan untuk "melunyah" mengalami kenaikan fisiologis (temperatur rektal, respirasi, dan denyut nadi) yang nyata $(\mathrm{P} \leq 0,05)$. Peningkatan parameter fisiologis pada ternak kerja terjadi karena pada saat kerja maka otot yang berkontraksi akan memproduksi panas sebagai produk sampingan metabolisme. Beberapa energi akan digunakan untuk kontraksi otot dan sebagian akan dilepas sebagai panas energi yang harus dihilangkan dengan berbagai cara proses pengaturan panas (thermoregulatory) untuk menjaga agar panas tubuh tetap normal sehingga kerja tetap dapat berlanjut (Moran, 1973; Nangia et al., 1980; Mathers et al., 1984; Pieterson and Ffoulkes, 1988).

Pada penelitian ini juga didapatkan hasil bahwa kenaikan temperatur rektal, respirasi, dan denyut nadi yang diukur SaatKerja berturut-turut adalah $1,05^{\circ} \mathrm{C}, 60,25$ (x/menit), dan 47,4 (x/menit). Hasil ini menunjukkan bahwa perubahan fisiologis akibat "melunyah" pada penelitian ini belum berbahaya bagi ternak. Hal ini mengacu pada hasil penelitian (Upadhyay and Madan, 1985) yang menyatakan bahwa kenaikan temperatur rektal sebesar $2,5^{\circ} \mathrm{C}$ adalah merupakan titik kritis bagi ternak kerja ruminansia. Diatas batas ini maka ternak tersebut atidak akan mampu melanjutnya kerjanya. Berdasarkan kategori tingkat kerja yang dilakukan maka "melunyah" dapat dimasukkan dalam kategori "kerja ringan" (Dwatmadji, 2000).

Pada penelitian ini juga diketahui bahwa setelah ternak istirahat selama 2 jam parameter fisiologis ternak belum dapat kembali pada kondisi awal (resting value).

\section{SIMPULAN}

- Semua parameter fisiologis (temperatur rektal, respirasi, dan denyut nadi) yang diukur mengalami kenaikan akibat "melunyah", dimana kenaikan tersebut belum berbahaya bagi ternak kerbau yang digunakan.

- Dari aspek kemampuan kerja maka kerja "melunyah" masuk dalam kategori kerja ringan.

\section{DAFTAR PUSTAKA}

Dwatmadji, 2000. Physiological and Metabolic Changes in Working Lactating Sheep. PhD Thesis, the Australian Institute of Tropical Veterinary and 
Animal Science, School of Biomedical and Molecular Sciences, James Cook University of North Queensland, Australia

Gemeda T., Zerbini E., Wold, A.G. and Demissie, D., 1995. Effect of draught work on performance and metabolism of crossbred cows. 1. Effect of work and diet on bodyweight change, body condition, lactation and productivity. Anim Science 60:361-367.

Kotsokoane, J.R.L., 1998. Towards 2000: Facing the realities of agriculture in South Africa before the turn of the century. South African Network of Animal Traction (SANAT) Newsletter 6(1): 18-22. University of Fort Hare, Alice, South Africa.

Mathers, J.C., Sneddon, C.J. and Thompson, C.J., 1984. Heat dissipation by working animals. Draught Animal News 2:3.

Moran, J.B., 1973. Heat tolerance of Brahman cross, buffalo, banteng and shorthorn steers during exposure to sun and as a result of exercise. Aust J Agric Res 24:775-782.
Nangia, O.P., Singth, N. and Sukhija, S.S., 1980. Effect of exercise on thermal and acid base balance in buffaloes. Trop Anim Hlth Prod 1:185-188.

Pearson, R.A. and Dijkman, J.T., 1994. Nutritional implications of work in draught animals. Proc Nutr Soc 53:169-179.

Pieterson, R. and Ffoulkes, D., 1988. Thermoregulatory responses in working buffalo with and without covers of wet hessian sacking. DAP Project Bull 5:23-28.

Ramaswamy, N.S., 1985 . Draught animal powerSocioeconomic Factors. In: Draught Animal Power for Production. JW Copland (ed), pp.20-25. ACIAR Proceedings Series No. 10, Canberra.

Starkey, P., 1995. Animal Traction in South Africa, Empowering Rural Communities. Development Bank of Southern Africa, Halfway House, South Africa.

Upadhyay, R.C. and Madan, M.L., 1985. Draft performance of Haryana and crossbred bullocks in different seasons. Indian J Anim Sci 55:50-54. 